\title{
Rethinking the Autonomic Nervous System
}

\author{
Janice Blumer* \\ Department of Neurology, Western University of Health Sciences, College of Osteopathic Medicine of the Pacific, USA
}

Submission: January 17, 2019; Published: March 13, 2019

*Corresponding author: Janice Blumer, Department of Neurology, Western University of Health Sciences, College of Osteopathic Medicine of the Pacific, FAAO, USA

Keywords: Physiology; Nervous system; Spinal cord; Sympathetic postganglionic; Basal system; Heart rate variability; Chronic dysfunctions; Consciousness; Fluctuations; Hypersympathetic; Hormonal system

Abbrevations: ANS: Autonomic Nervous System; PAG: Periaqueductal Grey matter; HRV: Heart Rate Variability

\section{Mini Review}

Historically, the Autonomic Nervous System (ANS) has been interpreted as all sympathetic tone or all parasympathetic tone with not much of a balance involved between the two. The view of the ANS may stem from how medical students learn the physiology of this system as "Fight or Flight" or "Feed and Breed", with no overlap between the two concepts, or view of the system as being complex and integrated with other body systems.

Anatomically, the sympathetic nervous system is composed of pathways that originate in neurons in cell bodies located from the first thoracic to the second lumbar vertebra. In contrast, the parasympathetic nervous system is composed of pathways that originate in neurons in cell bodies originating in the head region, including midbrain and medulla, and sacral portions of the spinal cord. Acetylcholine is the predominant neurotransmitter for parasympathetic postganglionic nerve endings where norepinephrine is the predominant neurotransmitter for the sympathetic postganglionic nerve endings [1].

Parasympathic effect is further developed by fibers around the arcuate nucleus that project into the Periaqueductal Grey matter (PAG). These cells are activated when parasympathetic effect is prevalent and release endocannabinoid like substances, furthering relaxation and downregulating pain in the dorsal horn [2-4]. We cannot forget the hormonal effects as a result of adrenal gland on this system, through the hypothalamic-pituitaryadrenal axis. The HPA axis is normally activated under stress and in response to pain in order to maintain homeostasis of the basal system. The adrenomedually system is also important in the role of homeostasis [5]. The central components of this system are located in the hypothalamus and the brain stem. The system is activated by many blood born signals, including cytokines produced by immune- mediated inflammatory reactions such as tumor necrosis factor alpha, interleukin-1, and interleukin-6 [6].

While many students perceive the ANS as a simple 'on or off' mechanism, it is extremely complex and has many influencing factors, including the hormonal system, which modulate our ability to function and find homeostatsis. One author discusses the "hypothalamic-pituitary-endocrine- autonomic- ganglionic nervous system that does not think for itself" and is often responsible for a "mass sympathetic discharge" effect [7]. In addition, so much of chronic disease affects the ANS and the patient's ability to find homeostasis it behooves us to understand this system in more depth. Decreased Heart Rate Variability (HRV) is a known physiologic effect of hypersympathetic tone. HRV is mediated through preganglionic sympathetic and parasympathetic neurons innervating the heart via the stellate ganglia and the vagus nerve respectively $[8,9]$. Parasympathetic influence on HRV is primarily mediated via the vagus nerve and is primarily responsible for the rapid changes in fluctuations in respiratory sinus arrhythmia and high frequency HRV. Sympathetic neural activity can alter cardiac HRV only slightly beat to beat. Reduced HRV is an indicator of cardiac risk and death from all causes [10]. It has also been linked to anxiety and emotional disorders in children [11,12].

For all these reasons, isn't about time that we give the ANS its due respect and stop teaching the oversimplified version that becomes embedded in the consciousness of students for their future careers. It is a complex and beautiful system that requires a deep dive into multiple systems to understand appropriately, and should be revisited often as the underlying cause of chronic dysfunctions. 


\section{References}

1. Cecil, Russell L, Smith LH (1985) Cecil textbook of medicine. WB Saunders.

2. Clark DL, Boutros NN, Mendez MF (2011) The brain and behavior: an introduction to behavioral neuroanatomy. Cambridge, MA: Cambridge University, Press, UK.

3. Liotta A, Advis JP, Krause JE, McKelvy JF, Krieger DT (1984) Demonstration of In vivo Synthesis of Pro-opiomelanocortin beta endorphin and alpha melanotropin-like species in the adult rat brain. J Neurosci 4(4): 956-965.

4. Chrousos GP (1995) The hypothalamic-pituitary-adrenal axis and immune-mediated inflammation. N Engl J Med 332(20): 1351-1362.

5. McPartland JM, Guy GW, Di Marzo V (2014) Care and Feeding of the Endocannabinoid System: A Systematic Review of Potential Clinical Interventions that Upregulate the Endocannabinoid System. PLoS ONE 9(3): e89566.

6. Capobianco JD (2005) The Collected Writings of Robert G, Thorpe DO, FAAO. Indianapolis, In: American Academy of Osteopathy, USA.

This work is licensed under Creative

Commons Attribution 4.0 Licens

DOI: 10.19080/OAJNN.2019.10.555777
7. Mcpartland JM (2008) The Endocannabinoid System: An Osteopathic Perspective. The Journal of the American Osteopathic Association. 108(10): 586-600.

8. Dekker JM, Crow RS, Folsom AR, Hannan PJ, Liao D (2000) Low heart rate variability in a 2-minute rhythm strip predicts risk of coronary heart disease and mortality from several causes: the ARIC Study. Atherosclerosis Risk In Communities. Circulation 102(11): 1239-1244.

9. Catherine Monk, Pavel Kovelenko, Lauren M Ellman, Richard P Sloan, Emilia Bagiella, et al.(2001) Enhanced stress reactivity in paediatric anxiety disorders: implications for future cardiovascular health. International Journal of Neuropsychopharmacology 4(2): 199-206.

10. Yeragani VK, Rao KR, Pohl R, Jampala VC, Balon R (2001) Heart rate and QT variability in children with anxiety disorders: A preliminary report. Depression and Anxiety13(2): 72-77.

11. Thayer JF. Stop That! Inhibition sensitization and their neurovascular concomitants. Scandinavian Journal of Psychology (43): 123-130.

12. Thayer JF (2009) Vagal tone and the inflammatory reflex. Cleve Clin J Med 76(Suppl_2): s23: 26.

\section{Your next submission with Juniper Publishers will reach you the below assets}

- Quality Editorial service

- Swift Peer Review

- Reprints availability

- E-prints Service

- Manuscript Podcast for convenient understanding

- Global attainment for your research

- Manuscript accessibility in different formats

( Pdf, E-pub, Full Text, Audio)

- Unceasing customer service

Track the below URL for one-step submission https://juniperpublishers.com/online-submission.php 